\title{
AKTIUITAS EKONOMI DAN PERDAGANGAN DI KERESIDENAN LAMPUNG PADA PERIODE 1856 HINGGA 1930
}

\author{
ECONOMIC AND TRADING ACTIVITIES IN LAMPUNG \\ IN THE PERIOD 1856 UNTIL 1930
}

\author{
Gregorius Andika Ariwibowo
}

Balai Pelestarian Nilai Budaya Jawa Barat

Jl.Cinambo No. 136, Ujungberung, Bandung

e-mail: andikaariwibowo@gmail.com

\begin{abstract}
Abstrak
Letaknya yang berada di ujung selatan Pulau Sumatera menjadikan wilayah Lampung sebagai titik penting dalam arus perdagangan Jawa-Sumatera. Pada masa kolonial wilayah tersebut merupakan salah satu daerah penghasil utama komoditas ekspor Hindia Belanda. Pembangunan yang dilakukan oleh pemerintah kolonial telah banyak mengubah wajah Lampung hingga kemudian menjadi salah satu daerah penting bagi perkembangan ekonomi di kawasan Sumatera bagian selatan. Kajian ini ingin melihat bagaimana bentuk dan gambaran dari aktivitas ekonomi dan perdagangan di wilayah Lampung pada periode 1856 hingga 1930. Kajian ini melihat perkembangan sejarah ekonomi di wilayah Lampung yang selama ini masih sedikit mendapatkan perhatian. Kajian ini menggunakan sumber-sumber dari laporan ekonomi pemerintah kolonial, serta artikel-artikel mengenai keadaan ekonomi di wilayah Lampung pada periode 1857 hingga 1930. Komoditas alam seperti lada, kopi, tembakau, dan karet menjadi penunjang bagi berkembangnya ekonomi dan perdagangan di Lampung. Pembenahan infrastruktur yang dilakukan oleh pemerintah kolonial memberikan pengaruh baik bagi pengembangan ekonomi di wilayah tersebut.
\end{abstract}

Kata kunci: Keresidenan Lampung, aktivitas ekonomi, perkembangan infrastruktur.

\begin{abstract}
The location on the southern tip of Sumatra Island makes the Lampung region as an important point in the Java-Sumatra trade flow. In the colonial period the region was one of the main producing areas of the Dutch East Indies export commodities. This study would like to see how the shape and picture of economic and trading activity in the area of Lampung in the period 1856 to 1930. In addition, this study also wants to see the type of physical development done by the colonial government to support economic activities in Lampung. This study aims to increase the repertoire of the study of economic history in the Lampung region which has received a little attention. Having a fertile and extensive area, has made Lampung as one of the centers of natural resource commodities in the Dutch East Indies. Natural commodities such as pepper, coffee, tobacco, and rubber are supporting the development of economy and trade. The improvement of infrastructure carried out by the colonial government had a good influence on economic development in this region.
\end{abstract}

Keywords: Lampung area, Economic activities, infrastructure development. 


\section{A. PENDAHULUAN}

Wilayah Lampung merupakan pintu gerbang menuju ke wilayah Sumatera. Wilayah ini menjadi jalur lalu lintas perdagangan dan ekonomi antara Jawa dan Sumatera. Kondisi ini kemudian membuat wilayah ini ramai dengan aktivitas ekonomi dan perdagangan. Dalam kegiatan dan aktivitas ekonomi pada masa sekarang ini, Provinsi Lampung tidak saja berperan sebagai jalur transportasi perdagangan, wilayah ini juga kaya dengan sumber daya alam yang memiliki nilai ekonomi yang tinggi. Kondisi wilayah pedalaman yang luas dan subur menjadikan Lampung dikenal sebagai salah satu pusat dari perkebunan karet, kopi, buah-buahan, palawija, aren, kelapa sawit, dan tebu termasuk juga dengan berbagai industri pengolahan dari produk-produk perkebunan tersebut. Selain itu sektor pertambangan juga menjadi andalan pemasukan daerah bagi Provinsi Lampung, terutama jenis pertambangan batu bara (BPS Lampung, 2015: 178-179, 264).

Aktivitas perdagangan maritim di Provinsi Lampung ditunjang oleh keberadaan dua pelabuhan utama di provinsi ini yakni Pelabuhan Panjang dan Pelabuhan Bakauheni. Keberadaan Pelabuhan Bakauheni dan Pelabuhan Panjang menjadi sarana penting dalam aktivitas dan lalu lintas perdagangan regional di wilayah ini. Kedua pelabuhan ini menjadikan Lampung sebagai salah satu pusat aktivitas ekonomi penting di wilayah Sumatera. Pelabuhan Bakauheni merupakan penghubung lalu lintas antara Jawa dan Sumatera. Kesibukan lalu lintas angkutan darat baik barang maupun penumpang antarkedua pulau ini nampak jelas dalam keseharian lalu lintas di Pelabuhan Bakauheni. Pelabuhan Panjang sendiri lebih banyak digunakan sebagai terminal perdagangan regional dan internasional terutama untuk komoditas ekspor (Pelindo II, 2012: 82; BPS Lampung, 2015: 288). ${ }^{1}$

Ramainya aktivitas ekonomi dan perdagangan di Provinsi Lampung tidak hanya berlangsung pada masa kini. Sebelumnya pada masa kolonial, Lampung juga telah memainkan peran penting sebagai salah satu pemasok kebutuhan sumber daya alam bagi perkembangan ekonomi Hindia Belanda. Berdasarkan catatan J.W.J. Wellan wilayah Keresidenan Lampung ketika itu merupakan penghasil utama bagi komoditas lada, kemenyan, kopi, kayu hasil hutan, kopra, dan rotan (Wellan, 1932: 223). Hal ini pun ditambah dengan catatan mengenai perbaikan dan pembangunan sarana transportasi di Lampung pada masa kolonial. Pengembangan dan perbaikan jalur jalan raya lintas timur Sumatera serta pembangunan jalur kereta api dari Teluk Betung (Lampung) hingga Muara Enim (Sumatera Selatan) pada tahun 1912 tentunya menjadi petunjuk dari tingginya tingkat aktivitas ekonomi di wilayah Lampung (De Graaf dan Stibbe, 1918, Tweede Deel: 513, 705, 712).

Berdasarkan hal tersebut maka kajian ini ingin melihat bagaimana bentuk dan gambaran dari aktivitas ekonomi dan perdagangan di wilayah Lampung pada periode 1856 hingga 1930? Kajian ini juga ingin melihat pembangunan sarana fisik

1 Berdasarkan keterangan PT Pelabuhan Indonesia II (Pelindo II) Pelabuhan Panjang termasuk salah satu pelabuhan terbesar di Pulau Sumatera pada saat ini. Pelabuhan ini memang lebih banyak digunakan untuk aktivitas bongkar muat peti kemas, serta menopang transportasi lintas regional untuk komoditas industri, pertambangan, dan perkebunan (Pelindo II, 2012: 82). Sementara itu Pelabuhan Bakauheni yang terletak di ujung selatan Pulau Sumatera lebih banyak digunakan untuk aktivitas pelayaran penumpang dan kendaraan, serta sarana penyeberangan menuju dan dari Pulau Jawa ke Pulau Sumatera. Pelabuhan Bakauheni juga melayani pelayaran penumpang antarpulau dan wilayah di sekitar Pulau Sumatera (BPS Lampung, 2015: 288) 
apa sajakah yang dilakukan oleh pemerintah kolonial untuk menunjang kegiatan ekonomi di Lampung, sekaligus juga apa saja jenis komoditas perdagangan penting yang berasal dari wilayah Lampung?

Kajian ini memulai pembahasannya pada tahun 1856. Tahun ini merupakan masa akhir dari rangkaian panjang Perang Lampung yang pecah sejak tahun 1818. Konsolidasi dan penegakan kembali kekuatan kolonial di wilayah Lampung oleh Belanda membuat wilayah ini kembali bergeliat dalam kegiatan ekonomi dan perdagangan. Kemunduran ekonomi Hindia Belanda yang dimulai pada tahun 1930 akibat resesi ekonomi turut menghantam fondasi utama sumber daya ekonomi Lampung yang sangat ditunjang oleh perdagangan komoditas tanaman lada serta berbagai tanaman produksi lain. Wilayah Lampung yang dalam kajian ini adalah wilayah Lampung pada masa kolonial Belanda yakni wilayah yang termasuk ke dalam wilayah Provinsi Lampung pada saat ini namun tidak termasuk wilayah Pesisir Barat Lampung yang ketika itu masuk ke dalam wilayah Keresidenan Bengkulu.

Minimnya kajian sejarah, khususnya dalam kajian sejarah ekonomi mengenai Keresidenan Lampung pada masa kolonial menjadi pendorong utama bagi penulisan kajian ini. Pengembangan dan perluasan penanaman lada, serta komoditas perkebunan lain oleh pemerintah kolonial pada masa sesudah perang, menjadikan wilayah ini kembali memainkan peran sentral dalam aktivitas ekonomi di Pulau Sumatera. Letak Lampung yang strategis sebagai pintu gerbang Sumatera telah menjadikan wilayah ini memainkan peran sentral dalam arus transportasi dan perdagangan di wilayah Sumatera. Hal ini tentunya merupakan suatu pembahasan yang menarik terutama dalam membahas kajian mengenai "Aktivitas Ekonomi dan Perdagangan di Keresidenan Lampung pada Periode 1856 hingga 1930”.
Thomas Linbald dalam salah satu artikelnya mengenai Outer Island (wilayah-wilayah di luar Pulau Jawa pada masa kolonial) mengatakan bahwa terdapat tiga faktor pendorong berkembangnya ekonomi dan perdagangan di wilayah ini pada abad ke-19. Faktor pertama yakni mulai terintegrasinya wilayah-wilayah di Kepulauan Hindia ke dalam satu pemerintahan di bawah sistem pemerintah kolonial Belanda. Ekspansi militer dan politik yang terjadi sepanjang abad ke-19 di sebagian besar wilayah Hindia pada akhirnya telah memberangus kekuasaankekuasaan politik lokal. Hal ini kemudian membuat pemerintah kolonial memiliki andil penuh terhadap upaya pengembangan dan ekploitasi ekonomi serta sumber daya alam di Hindia (Linbald dalam Dick, Houben, Linbald, dan Kian Wie, 2001: 8284).

Faktor pendorong kedua yakni terintegrasinya sistem jaringan pelayaran dan perdagangan maritim, terutama sejak kehadiran KPM sebagai maskapai perdagangan dan lalu lintas antarpulau. Berkembangnya kembali pelabuhanpelabuhan entreport di kota-kota pesisir di Hindia juga turut menjadi faktor terbentuknya kembali jaringan perdagangan maritim pada abad ke-19. Faktor terakhir yakni perluasan kembali sektor ekonomi Hindia Belanda, seperti pada sektor industri, hasil hutan, dan pertambangan. Selain itu pertumbuhan ekonomi global pada pertengahan abad ke19 telah membuka tanah Hindia bagi investasi para pengusaha di sektor swasta. Hal ini berdampak pada pembukaan lahanlahan baru, terutama untuk sektor tanaman industri dan hasil hutan (Linbald dalam Dick, Houben, Linbald, dan Kian Wie, 2001: 82-84, 88, 100-102).

Berkembangnya ekonomi Lampung semenjak periode abad ke-19 memang tidak bisa dilepaskan dari ketiga faktor pertumbuhan ekonomi di Outer-Islands sebagaimana yang dipaparkan oleh Linbald. Konsolidasi dan penguatan sistem politik kolonial sejak berakhirnya 
perlawanan Radin Intan II di Lampung telah menjadikan wilayah ini terbuka bagi pengembangan ekonomi. Letak Lampung yang menjadi penghubung dan jalur distribusi ekonomi antara Jawa dan Sumatera menjadikan wilayah ini bukan saja bermanfaat bagi penguatan pengaruh politik kolonial namun juga bagi pembangunan dan pengembangan sektor ekonomi dan perdagangan. Maka tidak heran apabila wilayah ini kemudian dijadikan sebagai salah satu tujuan transmigrasi pertama pada masa kolonial.

Kajian mengenai kondisi ekonomi Lampung pada abad ke-19 hingga abad ke20 sejauh ini memang belum banyak dibahas. Sejarah ekonomi mengenai Lampung lebih banyak membahas pada rentang periode sebelum abad ke-19. Pembahasan-pembahasan mengenai hal tersebut dapat ditemui dalam beberapa kajian dari Atsushi Ota (2005, 2013, dan 2015). Kajian-kajian yang dilakukan oleh Ota ini sangat penting dalam melihat kondisi ekonomi dan perdagangan di Lampung sebelum abad ke-19. Kajiankajian yang telah dilakukan oleh Atsushi Ota ini sekaligus menjadi latar belakang dari proses terbentuknya jaringan perdagangan antara Lampung dan wilayahwilayah lain di Hindia, serta melihat keragaman komoditas tanaman ekspor Lampung sebelum abad ke-19.

Beberapa penulis seperti Colombijn (2002), Gusti Asnan (2016), Tagliacozzo (2010), dan Rizal (2011) telah memberikan pandangan yang menarik bahwa pertumbuhan perdagangan dan perekonomian di Sumatera pada dekade awal abad ke-20 salah satunya ditunjang oleh pembangunan infrastuktur jalan, kereta api, dan pelabuhan. Kajian mengenai "Aktivitas Ekonomi dan Perdagangan di Keresidenan Lampung pada Periode 1856 hingga 1930" juga hendak melihat pengaruh dari pembangunan infrastuktur di Keresidenan Lampung pada masa kolonial bagi pertumbuhan dan perkembangan ekonomi di kawasan ini yang dilakukan oleh pemerintah kolonial.

Kajian Ariwibowo (2017) mengenai perkembangan Sungai Tulang Bawang dan perdagangan lada di Lampung menjadi salah satu artikel menarik untuk memberikan gambaran awal mengenai perdagangan lada di wilayah Lampung yang mulai berkembang sejak masa Kesultanan Banten. Ariwibowo (2017: 255-258) sekaligus menunjukkan bagaimana bentuk dari pola penanaman wajib hingga perdagangan lada di sekitar Sungai Tulang Bawang turut menopang pertumbuhan ekonomi Lampung pada masa kolonial.Kajian ini juga menunjukkan pasang surut Sungai Tulang Bawang sebagai sarana transportasi penting di Lampung sebelum berkembanganya kereta api pada tahun 1914. Kajian ini memberikan gambaran menarik dan aspek penting dalam melihat aspek perdagangan lada di Lampung pada masa kolonial

Pembangunan sarana dan infrastruktur di wilayah Lampung juga dilatarbelakangi oleh kolonisasi atau transmigrasi penduduk dari beberapa wilayah di Pulau Jawa ke Lampung sejak tahun 1905. Kajian-kajian mengenai transmigrasi pada kolonial ini telah dilakukan Levang dan Sevin (1989) Perluasan pengembangan ekonomi kolonial oleh pemerintah Hindia Belanda ketika itu salah satunya dilakukan dengan memindahkan sebagian petani-petani dari beberapa wilayah di Jawa. Upaya yang dilakukan oeh pemerintah kolonial pada satu sisi telah membantu peningkatan sarana dan infrastruktur di wilayah Lampung pada masa kolonial. Meskipun pada sisi lain tidak bisa dipisahkan begitu saja dampak dari problematika kolonialisme yang saling beririsan dengan pembangunan yang dilakukan (Levang dan Sevin, 1989: 3)

\section{B. METODE PENELITIAN}

Kajian ini menggunakan metodologi sejarah yang terdiri atas susunan pemilihan 
tema, penelusuran sumber data, verifikasi dan kritik sumber data, setelah itu dilakukan penulisan terhadap kajian ini. Sumber-sumber yang digunakan dalam penulisan kajian ini menggunakan berbagai literatur yang terdiri atas artikel, dokumentasi, laporan dan survey dalam bidang ekonomi dan perdagangan yang dilakukan oleh instansi pemerintah, individu, maupun lembaga nonpemerintah di wilayah Lampung pada periode 1857 hingg 1930.

Beberapa sumber milik pemerintah kolonial antara lain Koloniaal Verslag serta laporan-laporan yang dikeluarkan oleh Department van Binneland Bestuur, Department van Kolonien, dan Department of Public Works pemerintah Kolonial Hindia Belanda. Penggunaan sumbersumber dari arsip pemerintah ini sangat penting dalam melihat alur pembangunan infrastruktur dan upaya pemerintah kolonial dalam meningkatkan pertumbuhan ekonomi di kawasan ini.

\section{HASIL DAN BAHASAN}

\section{Kehidupan Ekonomi Masyarakat}

Sejak masa Kesultanan Banten masyarakat Lampung merupakan masyarakat yang berasal dari berbagai wilayah seperti dari wilayah Banten, Pasundan, Palembang, Bugis, Jawa, Melayu, dan Tionghoa (De Graaf dan Stibbe, 1918, Tweede Deel: 508). Wilayah Lampung mulai berkembang dalam bidang ekonomi dan perdagangan semenjak masa Kesultanan Banten terutama sejak wilayah ini dijadikan sebagai perkebunan lada Kesultanan sejak awal abad ke-17 (Ariwibowo, 2017: 255). Lada kemudian menjadi daya tarik utama bagi para pendatang untuk turut bekerja maupun membuka perkebunan-perkebunan di wilayah Lampung, terutama di sepanjang Sungai Tulang Bawang (Kielstra, 1915: 245; Ariwibowo, 2017: 257).

Pada tahun 1860 yang merupakan periode selepas Perang Lampung jumlah penduduk di wilayah Keresidenan Lampung berjumlah 107.725 jiwa (Staat der Bevolking tan de bezzittingenbuiten Java en Madoera, 1860: 14-15). Para penduduk ini sebagian besar bekerja di sektor pertanian dan perkebunan, serta beberapa sebagai nelayan baik di sungai maupun di sekitar pantai. Kehidupan masyarakat pada masa pertengahan abad ke-19 ini hanya terbatas di wilayah kotakota dagang dan pusat penanaman lada di wilayah Tulang Bawang dan Teluk Betung.

Tabel 1. Jumlah Penduduk di Keresidenan Lampung Tahun 1860 Sampai 1920

\begin{tabular}{cc}
\hline Tahun & Jumlah Penduduk \\
\hline 1860 & 107.725 \\
\hline 1882 & 142.000 \\
\hline 1900 & 141.364 \\
\hline 1905 & 155.180 \\
\hline 1912 & 157.781 \\
\hline 1920 & 233.903 \\
\hline
\end{tabular}

Sumber: Staat der Bevolking tan de bezzittingenbuiten Java en Madoera, 1860: 1415; Steck, 1862: 108; Blink, 1926: 41)

Sebelum jalan raya dan transportasi menjadi pilihan utama dalam arus lalu lintas kehidupan masyarakat di wilayah Lampung, sungai memainkan peran sentral dalam kehidupan masyarakat. Kehidupan masyarakat Lampung sangat bergantung pada keberadaan dan fungsi sungai. Pola pemukiman di wilayah ini berada di sekitar bibir sungai. Sungai Tulang Bawang yang merupakan salah satu sungai terbesar dan terpanjang di wilayah Lampung merupakan contoh ketergantungan antara sungai dan kehidupan masyarakat (Ariwibowo, 2017: 257). Di sekitar sungai Tulang Bawang terdapat kampungkampung kecil yang menjadi tempat singgah bagi kapal-kapal yang hendak membeli atau mendistribusikan lada. Sungai Tulang Bawang juga menjadi sarana transportasi bagi para imigran yang berasal dari wilayah pedalaman Palembang maupun para penduduk dari Banten yang mencoba peruntungan sebagai pekerja di perkebunan-perkebunan lada. Sungai ini juga menjadi sarana bagi irigasi yang 
mengairi perkebunan dan persawahan (Ariwibowo, 2017: 256-257; Ota dalam Mizushima, Bryan Souza, dan Flynn, 2015: 177).

Penduduk mengandalkan perahu untuk berlalu lintas dan berdagang di sepanjang sungai. Salah satu kota pedalaman yang memiliki pengaruh cukup penting sebelum abad ke-20 di wilayah Lampung adalah Kota Menggala. Kota ini merupakan pelabuhan utama di jantung Sungai Tulang Bawang yang menjadi pasar bagi komoditas-komoditas lada dan aneka kebutuhan penduduk. Kota Menggala juga menjadi tempat pertemuan dan aktivitas ekonomi bagi penduduk yang berasal dari wilayah Komering (Palembang) hingga ke wilayah sekitar Lampung. Penduduk dalam aktivitas kesehariannya menggunakan perahuperahu tradisional seperti sampan, tambangan, dan rakit untuk membawa barang dagangan atau pun saling berkunjung antarkampung di sepanjang aliran sungai (Marsden, 2013 (1810): 4546). Pada tahun 1905 transmigran dari Jawa mulai mendiami wilayah Lampung. Transmigrasi atau yang pada periode tersebut dikenal dengan nama kolonisasi di wilayah Lampung sejak tahun 1905. Pemerintah Kolonial Hindia Belanda menjadikan kolonisasi ini sebagai upaya untuk "memenuhi" tanggal jawab mereka dalam pelaksanaan program Politik Etis yang mewajibkan mereka untuk meningkatkan pertumbuhan ekonomi di luar Jawa sekaligus sebagai salah satu cara untuk mengurangi kepadatan penduduk di wilayah Jawa (Levang dan Sevin, 1989: $3){ }^{2}$

2 Program Politik Etis ini pertama kali diwacanakan oleh beberapa anggota Parlemen Belanda untuk mengurangi kemiskinan dan kesengsaraan penduduk Jawa akibat program Cultuurstelsel. Salah satu program Politik Etis atau Politik Balas Budi ini adalah melakukan emigrasi penduduk Jawa ke wilayah-wilayah lain di luar Jawa yang masih memiliki potensi ekonomi lain sehingga diharapkan meningkatkan potensi ekonomi dan
Kolonisasi yang dilakukan oleh pemerintah kolonial membawa pengaruh penting dalam pertumbuhan dan perkembangan ekonomi di wilayah Lampung. Transmigran ini diberikan berbagai fasilitas untuk membuka lahanlahan untuk pengembangan tanaman produksi dan industri. Tercatat hingga tahun 1932 para transmigran ini telah membangun sekitar 71.000 hektar hutan tanaman produksi di wilayah Lampung. Pertumbuhan penduduk akibat transmigrasi di wilayah Lampung juga turut meningkatkan konsumsi. Pemerintah kolonial kemudian membangun berbagai sarana irigasi dan pertanian agar tidak terjadi krisis pangan di wilayah ini akibat pertumbuhan penduduk (Levang dan Sevin, 1989: 3).

Transmigrasi yang dilakukan oleh pemerintah kolonial ini memiliki arti penting bagi pertumbuhan ekonomi di Lampung sejak dekade pertama awal abad ke-20. Pembukaan lahan-lahan baru oleh pemerintah dan swasta menjadikan wilayah ini sebagai salah satu sumber pemasukan bagi pemerintah kolonial. Transmigrasi juga memiliki fungsi bagi munculnya kota-kota baru di wilayah ini. Kota-kota seperti Bagelen, Wonosobo, Pringsewu, dan Metro menjadi pusat dari aktivitas transmigran di wilayah Lampung. Jaringan jalan yang telah tertata dengan baik menghubungkan kota-kota ini dengan wilayah Teluk Betung telah mengubah prespektif geografis di wilayah Lampung dari yang sebelumnya mengandalkan keberadaan dan fungsi sungai.

kesejahteran para penduduk Jawa di wilayahwilayah lain. Hal ini kemudian dimanfaatkan oleh pemerintah kolonial untuk memperluas jaringan ekonomi dan perdagangan mereka dengan membuka sumber-sumber daya ekonomi baru serta pembangunan fasilitas umum di luar wilayah Jawa (Levang dan Sevin, 1990: 3). 


\section{Potensi Ekonomi dan Perdagangan}

Wilayah Lampung terletak di bagian selatan Pulau Sumatera. Pada masa kolonial wilayah ini berbatasan dengan Keresidenan Palembang (Keresidenan Komering Ilir) di bagian utara, serta dengan Asisten Residensi Bengkulu (Keresidenan Krui), ${ }^{3}$ dan Residensi Palembang (Distrik Komering Ulu) di bagian barat. Sementara di bagian timur berbatasan dengan Laut Jawa, serta dengan Selat Sunda di bagiansSelatan (Steck, 1862: 70; Gelder, 1916). yang kemudian turut menumbuhkan industri kopra di kawasan ini.

Masyarakat Lampung pada masa kolonial mengenal dua jenis pola pertanian yakni sawah lebak (rawa) dan sawah irigasi. Kondisi lingkungan tinggal masyarakat Lampung yang berada di sekitar pinggir-pinggir sungai menjadikan sungai memiliki arti penting dalam upaya pemenuhan kebutuhan konsumsi masyarakat. Selain memancing ikan di sungai mereka juga mengembangkan jenis pertanian sawah lebak (rawa). Tanah-tanah

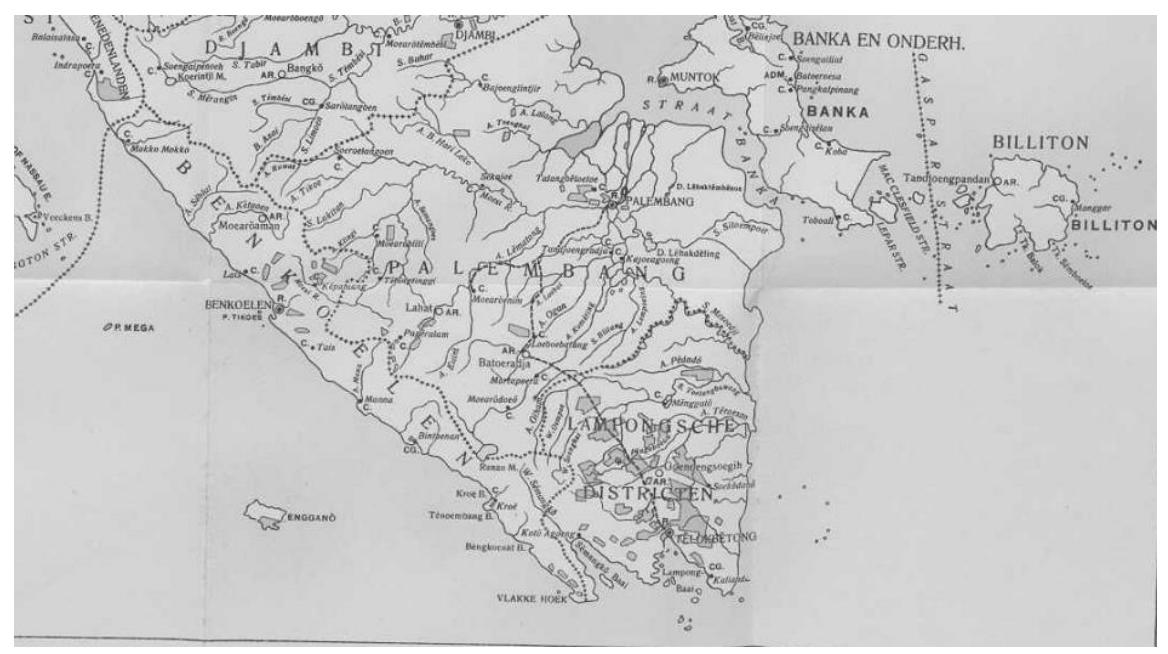

Gambar 1: Atlas wilayah Lampung dan Sumatera bagian selatan.

Sumber: Departement van Binnenlandsch Bestuur, 1915.

Bentang alam wilayah Lampung menunjukkan kekayaan potensi ekonomi dan hasil bumi di wilayah ini. Sungai yang lebar dan panjang memiliki fungsi sebagai penunjang kehidupan masyarakat Lampung. Daerah-daerah perbukitan dan hutan belantara yang membentang luas dari sisi bagian barat hingga utara menjadikan wilayah ini sebagai daerahdaerah perkebunan terutama untuk jenis tanaman kopi dan hasil hutan. Di wilayah pesisir selatan dan timur tanaman kelapa tumbuh subur dan ditanam secara luas

3 Wilayah Krui pada saat ini merupakan wilayah Kabupaten Pesisir Barat, Provinsi Lampung rawa kering - biasanya surut secara alamiah pada musim kemarau dibuatkan kanal-kanal kecil dari sungai untuk mengairi air ke sawah-sawah milik para penduduk. Pola pertanian sawah irigasi - seperti yang terdapat di Jawa mulai berkembang sejak para penduduk Banten mulai mendiami wilayah ini pada sekitar abad ke-17. Pola pertanian ini kemudian semakin berkembang seiring dengan kolonisasi (transmigrasi) para penduduk dari Jawa sejak tahun 1905. Selain itu, para penduduk juga menanam jenis tanaman pangan lain seperti jagung dan umbi-umbian (De Graaf dan Stibbe, 1918, Tweede Deel: 509-510).

Sektor perikanan baik laut maupun sungai juga menjadi salah satu sumber 
pendapatan bagi masyarakat. Salah satu pusat penangkapan ikan yang besar pada masa kolonial yakni berada di sekitar perairan Teluk Lampung. Ikan-ikan tersebut kemudian dipasarkan di pasar sekitar wilayah Teluk Betung dan Tanjung Karang, sebelum nantinya dipasarkan ke wilayah-wilayah lain di Lampung. Pada tahun 1919 terdapat perusahaan penangkapan dan pengolah ikan yang cukup besar di Keresidenan Lampung yang bernama "Perbandaharaan" yang pada penutupan buku tahun tersebut memiliki pendapatan hingga sebesar $f 160.000$ (De Graaf dan Stibbe, 1918, Tweede Deel: 512; Koloniaal Verslag, 1920: 114).

Perkebunan memegang peranan penting dalam perkembangan ekonomi di wilayah Lampung pada masa kolonial. Komoditas perkebunan terbesar yang berasal dari Lampung pada masa kolonial antara lain lada, kopi, kopra, damar, dan rotan (Wellan, 1932: 223). Pada awal abad ke-20, karet mulai dikembangkan di Lampung, meskipun dibandingkan dengan wilayah lain di sekitarnya seperti Palembang dan Jambi jumlah produksi karet di Lampung masih sangat tertinggal. Tercatat hanya sekitar 50 ton produksi karet di Lampung pada tahun 1914, hal ini dapat dibandingkan dengan hasil karet Keresidenan Palembang yang mencapai sekitar 3.780 ton (Departement van Binnenlandsch Bestuur, 1915: 130).

Peraturan pertama mengenai pengaturan kepemilikan dan pengelolaan perkebunan di wilayah Lampung ditetapkan pada tahun 1855. Peraturan ini menetapkan syarat kepemilikan dan pengelolaan serta batasan pengelolaan oleh pengusaha Bumiputera, Timur Asing, maupun Eropa. Pada tahun 1914 pemerintah kolonial telah memberikan konsensus kepemilikan lahan perkebunan kepada sekitar 166 pengusaha dimana $7 \mathrm{di}$ antaranya merupakan pengusaha bumi putra. Para pengusaha perkebunan ini mengelola sekitar 519.000 bau lahan perkebunan dari mulai lada hingga tanaman karet (Departement van Binnenlandsch Bestuur, 1915: 39).

Lada merupakan sumber utama penghasilan bagi pemerintah kolonial dari Keresidenan Lampung. Pada tahun 1914 Lampung menghasilkan sekitar 13.207 ton lada bagi Hindia Belanda. Lampung telah dikenal sebagai penghasil lada utama di Hindia Belanda sejak abad ke-17. Hingga menjelang malaise ekonomi dunia pada tahun 1930, lada tetap menjadi primadona komoditas ekspor Lampung untuk memenuhi permintaan pasar rempahrempah dunia.

Tabel 2. Produksi Lada Lampung dalam Rentang Periode 1923 hingga 1930

\begin{tabular}{cc}
\hline Tahun & $\begin{array}{c}\text { Jumlah Produksi } \\
\text { (dalam ribu kilogram) }\end{array}$ \\
\hline 1923 & 17.762 \\
\hline 1925 & 14.828 \\
\hline 1927 & 9.396 \\
\hline 1930 & 15.812 \\
\hline
\end{tabular}

Sumber: Wellan, 1932: 250.

Setelah mengalami jatuhnya produksi lada pada periode akhir abad ke18 hingga pertengahan abad ke-19 pemerintah kolonial mulai kembali berusaha meningkatkan produksi lada di Lampung. Setelah menjadikan wilayah Lampung sebagai bagian dari wilayah pemerintahan Hindia Belanda pada tahun 1856 sebagai langkah pertama dalam usaha perbaikan produksi lada maka pemerintah kolonial melakukan perbaikan secara menyeluruh perkebunan lada yang masih tersisa. Pemerintah memerintahkan para penduduk untuk membersihkan lahanlahan perkebunan lada yang rusak, merevitalisasi perkebunan yang masih berproduksi, serta membuka kembali perkebunan-perkebunan baru (Koloniaal Verslag, 1858: 7; Koloniaal Verslag, 1859: 7).

Penduduk diwajibkan untuk menanam pohon lada sekitar 333 hingga 1.000 pohon per kepala keluarga yang disesuaikan dengan luas tanah dan jumlah 
anggota keluarga. Penanaman wajib ini dilakukan untuk meningkatkan pendapatan dan produksi tanaman lada dari wilayah Lampung. Pemerintah kolonial mengawasi dengan ketat seluruh rangkaian produksi lada. Pada dekade-dekade awal dari kebijakan pemerintah kolonial ini terjadi krisis beras di wilayah Lampung. Hal ini kemudian berdampak pada terjadinya kelaparan yang sangat luas di wilayah ini. Akibatnya pemerintah kolonial harus mengirimkan beras dari Bengkulu, Palembang, dan Jawa selama beberapa tahun (Koloniaal Verslag, 1859: 7; Anonim, 1918: 33).

Perkebunan-perkebunan lada tidak dikelola langsung oleh pemerintah kolonial. Kebun-kebun ini sebagian besar dikelola oleh perkebunan-perkebunan swasta milik orang Eropa dan Tionghoa. Di wilayah-wilayah seperti di Katimbang, Teluk Betung, dan Semangka perkebunanperkebunan lada ini dikelola oleh orang Eropa. Sedangkan di wilayah-wilayah seperti di Seputih dan Tulang Bawang dikelola oleh orang-orang Tionghoa (Anonim, 1918: 38).

Wilayah-wilayah yang menjadi pusat dari budidaya lada di Lampung berada di wilayah Semangka, Katimbang, Teluk Betung, Seputih, Sekampung, dan Tulang Bawang. Luas lahan penanaman lada pada tahun 1918 mencapai sekitar 7.309 bau, selain itu masih terdapat sekitar 1470 bau perkebunan tanaman lada yang belum berproduksi (Anonim, 1918: 39). Perdagangan lada di Lampung sebagian besar dilakukan oleh pedagang Eropa dan Tionghoa. Lada-lada yang berasal dari pedalaman wilayah Lampung dikumpulkan di dua bandar lada di wilayah ini yakni Menggala ibukota afdeeling SeputihTulang Bawang serta pelabuhan dagang utama di Teluk Betung. Lada-lada yang memiliki kualitas baik biasanya segera diserahkan kepada pedagang besar Eropa dan Tionghoa untuk dikirimkan ke Batavia atau langsung ke Eropa. Sementara ladalada yang berkualitas kurang baik biasanya diperdagangkan kembali oleh para pedagang Tionghoa ke pelabuhanpelabuhan regional di Muntok (Pulau Bangka), Rantau Jaya Ilir (Palembang), maupun Labuan Maringai (Lampung Timur) (Anonim: 1918: 38-39).

$$
\text { Apabila dibandingkan dengan }
$$

Palembang maupun Bengkulu pengembangan budi daya kopi di Lampung cukup tertinggal. Menurut J.W.J. Wellan, tanaman kopi baru dibudidayakan menjadi tanaman wajib bagi masyarakat Lampung pada dekade pertama abad ke-20. Sementara di Palembang budi daya kopi telah berlangsung sejak tahun 1850-an (Wellan, 1932: 108). Pada tahun 1929 Keresidenan Lampung menghasilkan 6.526 ton kopi sedangkan Keresidenan Palembang dan Keresidenan Bengkulu menghasilkan 20.073 ton dan 13.887 ton. $^{4}$ Jenis kopi yang ditanam di wilayah Sumatera bagian selatan (Zuid Sumatra) pada umumnya adalah jenis kopi robusta. Di Lampung perkebunan kopi rakyat rupanya lebih dominan dibandingkan dengan perkebunan-perkebunan yang dikelola oleh pengusaha swasta. Perkebunan kopi rakyat di Lampung pada tahun 1929 menghasilkan produksi hingga sebesar 5.080 ton sedangkan perkebunan yang dikelola swasta hanya mencapai 1.424 ton (Wellan, 1932: 256-258).

Perkebunan rakyat untuk tanaman kopi di Lampung pada periode kolonial

\footnotetext{
${ }^{4}$ Sebuah catatan menarik adalah pada tahun 2013 hasil produksi perkebunan kopi di Lampung mencapai 127.073 ton dengan pusat perkebunan yang berada di wilayah Kabupaten Lampung Tengah, Kabupaten Tenggamus dan Kabupaten Lampung Barat. Sementara wilayah Bengkulu hanya menghasilkan 56.142 ton (Dirjen Perkebunan, 2014: 5). Peningkatan jumlah produksi kopi di Provinsi Lampung dan Provinsi Bengkulu yang seakan berbanding terbalik dibandingkan pada masa kolonial salah satunya disebabkan oleh masuknya wilayah Kabupaten Tenggamus dan Kabupaten Lampung Barat ke dalam wilayah Provinsi Lampung. Sedangkan pada masa kolonial kedua wilayah ini termasuk ke dalam wilayah Keresidenan Bengkulu.
} 
sangat ditunjang oleh pertumbuhan dan perkembangan kolonisasi atau transmigrasi yang mulai dilakukan sejak tahun 1905 . Kopi menjadi komoditas penting selain lada, kapas, palawija, dan beras yang dibudidayakan oleh para transmigran (Wellan, 1932: 108). Semenjak itulah terjadi peningkatan pendapatan dari budidaya tanaman kopi di wilayah ini. Pada tahun 1929 wilayah Keresidenan Lampung memperoleh sekitar $f$ 4.604.000 dari ekspor perdagangan kopi. Budidaya tanaman kopi ini terus bertahan bahkan pada masa setelah malaise, kopi menjadi tanaman unggulan bagi wilayah Lampung. Hal ini terjadi akibat berkurangnya popularitas lada di pasar internasional serta wabah hama yang menyerang tanaman lada sehingga menyurutkan produksi lada di Lampung (Wellan, 1932: 223).

Tabel 3. Produksi Kopi di Lampung dalam Rentang Periode 1923-1929

\begin{tabular}{ccc}
\hline Tahun & $\begin{array}{c}\text { Total } \\
\text { Produksi } \\
\text { (dalam ribu } \\
\text { kilogram) }\end{array}$ & $\begin{array}{c}\text { Nilai Produksi } \\
\text { (dalam ribu } \\
\text { Gulden) }\end{array}$ \\
\hline 1923 & 1.482 & 824 \\
\hline 1925 & 2.142 & 1.959 \\
\hline 1927 & 3.278 & 2.333 \\
\hline 1929 & 6.526 & 4.604 \\
\hline
\end{tabular}

Sumber: Wellan, 1932: 256.

Jenis tanaman kopi yang dibudidayakan di Lampung adalah jenis kopi Arabika, Robusta, dan Liberia. Jenis kopi robusta merupakan jenis kopi yang paling banyak dibudidayakan di wilayah ini. Hal ini karena sebagian besar para transmigran mengembangkan budidaya kopi robusta. Perkebunan kopi robusta memang telah mendominasi perkebunan kopi di wilayah Sumatera bagian selatan sejak masa awal penanaman kopi oleh pemerintah kolonial sekitar akhir dekade 1850an. ${ }^{5}$ Pada masa kini sekitar 2/3

${ }^{5}$ Produksi-produksi awal perkebunan kopi di Lampung salah satunya tercatat pada tahun produksi kopi robusta di Indonesia berasal dari wilayah Sumatera bagian selatan. Meskipun memiliki harga yang terbilang lebih rendah dibanding jenis kopi arabika yang banyak tersebar di Aceh, Sumatra Utara, Jawa Tengah, dan Indonesia bagian timur, namun kopi robusta memiliki keunggulan dalam daya tahan tanaman dari serangan hama dan penyakit, serta kemudahan dalam proses penanaman dan pemeliharaan. Hal inilah yang kemudian mendorong pemerintah kolonial untuk mendorong budi daya tanaman kopi robusta di wilayah Sumatra bagian selatan yang mencakup wilayah Sumatra Selatan, Bengkulu, dan Lampung (Wellan, 1932: 258; Kwan dan Cervone, 2014: 1).

Salah satu sektor perkebunan lain yang menjadi sumber pemasukan utama di wilayah Lampung pada awal abad ke-20 adalah karet. Karet menjadi primadona sejak masa "ledakan karet" pada sekitar tahun 1908 sampai 1910. Berkembangnya industri otomotif dan manufaktur pada masa tersebut meningkatkan permintaan terhadap kebutuhan karet oleh sektor industri baik di Hindia Belanda maupun Dunia. Lampung merupakan salah satu daerah penghasil karet terbesar di Sumatera di samping wilayah Sumatera Timur, Riau, dan Aceh. Pada tahun 1913 tercatat sekitar 54.000 bau luas perkebunan karet di wilayah Lampung. Konsesi kepemilikan lahan perkebunan karet di wilayah Lampung ini dimiliki oleh sekitar 20 perusahaan perkebunan (Department van Binnenlandsch Bestuur, 1915: 252255).

Sektor pertambangan sebenarnya bukan merupakan sektor pendapatan utama bagi wilayah Lampung pada masa kolonial. Dibandingkan dengan daerah sekitarnya seperti Palembang, Bengkulu,

1859. Pada tahun tersebut wilayah Lampung memiliki sekitar 1,7 juta pohon kopi serta masih terdapat 1,2 juta pohon lagi yang belum berproduksi. Dari jumlah sekitar 1,7 juta pohon tersebut dihasilkan sekitar 585 pikul biji kopi (Koloniaal Verslag, 1860: 141-142). 
Sumatera Barat, Riau, dan Jambi yang kaya dengan sumber daya mineral seperti emas, perak, batu bara, minyak bumi, perunggu, dan berbagai jenis barang tambang lain, wilayah Lampung pada periode awal abad ke-20 dikenal sebagai penghasil pasir besi. Hingga tahun 1913 terdapat empat perusahaan yang memiliki konsesi penambangan pasir besi di wilayah Lampung. Keempat pemilik konsesi penambangan pasir besi ini memiliki luas cakupan wilayah penambangan sekitar 999 hektar yang sebagian besar berada di wilayah sekitar Teluk Lampung (Department van Binnenlandsch Bestuur, 1915: 127).

Tabel 4. Nilai Ekspor Perdagangan dari Wilayah Lampung 1881-1923

\begin{tabular}{cc}
\hline Tahun & $\begin{array}{c}\text { Nilai Ekspor (dalam } \\
\text { Gulden) }\end{array}$ \\
\hline 1881 & 47.000 \\
\hline 1910 & 452.000 \\
\hline 1922 & 3.214 .000 \\
\hline 1923 & 5.997 .000 \\
\hline
\end{tabular}

Sumber: Blink, 1926: 110.

\section{Pengembangan Sarana dan Fasilitas Perdagangan}

Menurut Fernand Braudel (1983, vol

2: 140) terbentuknya rangkaian jalur perdagangan (trade circuit) yang ditunjang oleh pertumbuhan sarana transportasi merupakan salah satu aspek penting bagi perkembangan dan pertumbuhan ekonomi di suatu kawasan. Adanya saling ketergantungan antara kebutuhan akan ketersediaan komoditas perdagangan serta pasar yang menjadi ruang dalam transaksi jual beli di dalam rangkaian jalur perdagangan ini telah menciptakan kemakmuran dan kemajuan pada pusatpusat perdagangan yang terdapat dalam suatu rangkaian jalur perdagangan. Berdasarkan pendapat Braudel ini maka Howard Dick dan Peter J. Rimmer (2003: 4) mengatakan bahwa perkembangan teknologi dan sarana transportasi di sepanjang abad ke-19 dan awal abad ke-20 telah memainkan peran penting dalam menciptakan pertumbuhan ekonomi dan konsumsi; penggerak arus perdagangan, komunikasi, dan penduduk; serta menciptakan dinamika serta struktur perdagangan global termasuk juga di kawasan Asia Tenggara dan Hindia Belanda. Termasuk pula bagi Keresidenan Lampung juga turut memainkan aspek penting dalam perkembangan sarana transportasi yang mendukung perkembangan dan pertumbuhan ekonomi di wilayah Sumatera dan Hindia Belanda.

Pada periode abad ke-17 hingga awal dekade abad ke-19 sungai merupakan sarana penting dalam lalu lintas perdagangan dan ekonomi di wilayah Lampung. Sungai merupakan urat nadi bagi mobilitas masyarakat dan arus perdagangan di kawasan ini. Beberapa sungai yang cukup besar di wilayah ini antara lain Sungai Tulang Bawang, Sungai Mesuji, Sungai Semangko, Sungai Sekampung, dan Sungai Seputih (De Graaf dan Stibe, 1918: 509; Wellan, 1932: 11). Sungai Tulang Bawang merupakan salah satu sungai yang menjadi urat nadi ekonomi dan perdagangan di Lampung sejak masa Kesultanan Banten di abad ke17.

Ariwibowo (2017: 253-267) mengatakan bahwa Sungai Tulang Bawang menjadi jalur utama arus perdagangan lada di Lampung hingga sekitar tahun 1914 atau sebelum penggunaan jalur kereta api yang menghubungkan Lampung hingga Palembang. Sepanjang abad ke-19 Sungai Tulang Bawang menjadi jalur transportasi perdagangan lada di wilayah Sumatera bagian selatan. Perusahaan-perusahaan perkapalan milik orang Tionghoa dan sebagian milik KPM menguasai aktivitas pelayaran di sungai ini (Ariwibowo, 2017: 263-266). Namun fungsi Sungai Tulang Bawang sebagai jalur transportasi perdagangan ini semakin berkurang seiring dengan pembangunan jalan raya lintas timur Sumatera dan pembangunan jalur 
kereta api Teluk Betung-Palembang. ${ }^{6}$ Pembangunan jalan raya lintas timur Sumatera di wilayah Lampung pertama kali dilakukan pada masa pemerintahan Residen R. Wijnen (1857-1861). Jalan Raya ini menghubungkan wilayah Teluk Betung hingga ke Kota Menggala. Jalan raya ini pada awalnya merupakan jalan setapak yang digunakan oleh para petani lada untuk membawa hasil lada mereka ke Kota Menggala yang merupakan bandar lada utama di kawasan ini. Setelah berakhirnya Perang Lampung pemerintah kolonial mulai mengusahakan kemudahan komunikasi dan transportasi antarkawasan di wilayah Karesidenan Lampung. Pembangunan sarana jalan raya ini pada mulanya didasari oleh pertimbangan bagi kepentingan militer dan keamanan selepas Perang Lampung. Pada masa selanjutnya jalan raya ini mulai digunakan bagi arus mobilitas perdagangan dan penduduk yang

6 Upaya pemerintah kolonial dalam meningkatkan pendapatan ekonomi mereka dari hasil alam yang berasal dari Karesidenan Lampung pada akhirnya memberikan dampak penting atas hilangnya fungsi sungai sebagai jalur transportasi dan perdagangan di Lampung. Wilayah afdeeling Tulang Bawang dengan Menggala sebagai kota dagang di wilayah ini memang menyimpan potensi kekayaan alam yang sangat besar. Pemerintah kolonial menyadari bahwa ketergantungan pada transportasi Sungai Tulang Bawang tidak akan serta merta meningkatkan pendapatan mereka dari wilayah ini. Pada tahun 1901 wilayah Tulang Bawang mampu menghasilkan pendapatan hingga $f 331.000$, dengan hanya mengandalkan transportasi dari kapal uap atau biasa disebut "ophir" tentu akan memakan waktu yang panjang untuk mendistribusikan hasil bumi dari Mengala hingga ke Teluk Betung, bahkan adanya keterbatasan muat kapal dalam proses distribusinya. Sehingga pembangunan jalan raya serta jalur kereta api diharapkan oleh pemerintah kolonial ketika itu akan meningkatkan pendapatan dan memperluas perkebunan-perkebunan khususnya lada dari wilayah Tulang Bawang dan sekitarnya (Department van Kolonien, 1904: 66). kemudian turut meningkatkan perekonomian di kawasan Lampung. Hal ini dapat dilihat dari jalur jalan raya ini yang melewati perkebunan-perkebunan lada di wilayah Afdeeling Seputih, Terbanggi, dan Sekampung (Stibbe, 1921: 427).

Pada tahun 1870 di masa Residen A. Pruys van der Hoeven jalan raya Teluk Betung - Menggala dapat digunakan sepenuhnya untuk arus lalu lintas perdagangan dan mobilitas penduduk. Pembangunan jalan raya ini kemudian diikuti dengan perkembangan kawasankawasan ekonomi dan pemukiman baru di sepanjang jalur ini (Stibbe, 1921: 427). Dampak dari pembangunan jalan raya ini adalah mulai ditinggalkannya beberapa sungai seperti Sungai Tulang Bawang, Sungai Seputih, dan Sungai Sekampung sebagai jalur perdagangan di kawasan ini. Pembangunan jalur kereta api antara Teluk Betung hingga Palembang pada tahun 1912 semakin membuat ditinggalkannya fungsi sungai sebagai jalur perdagangan di wilayah Keresidenan Lampung (Ariwibowo, 2017).

Pada tahun 1902 melalui Besluit yang dikeluarkan oleh Gubernur Jenderal Hindia Belanda pada 16 Februari 1902, pemerintah kolonial Hindia Belanda menetapkan pembangunan jalur kereta api lintas Sumatera bagian selatan (Zuid Sumatra) yang meliputi jalur kereta api dari Teluk Betung (Lampung) hingga ke Palembang (Department van Kolonien, 1904: 1). Alasan utama dari pembangunan jalur kereta api ini adalah meningkatnya pertumbuhan ekonomi dan perdagangan di wilayah Zuid Sumatra sejak dekade terakhir abad ke-19. Minyak bumi, lada, damar, kopra, tembakau, kopi, karet, kemenyan dan coklat merupakan sumber ekonomi penting di kawasan Zuid Sumatra yang meliputi tiga wilayah keresidenan yakni Lampung, Palembang, dan Bengkulu (Department van Kolonien, 1904 1906: 23).

Pembangunan jalur kereta api Zuid Sumatra dibagi ke dalam beberapa tahap 


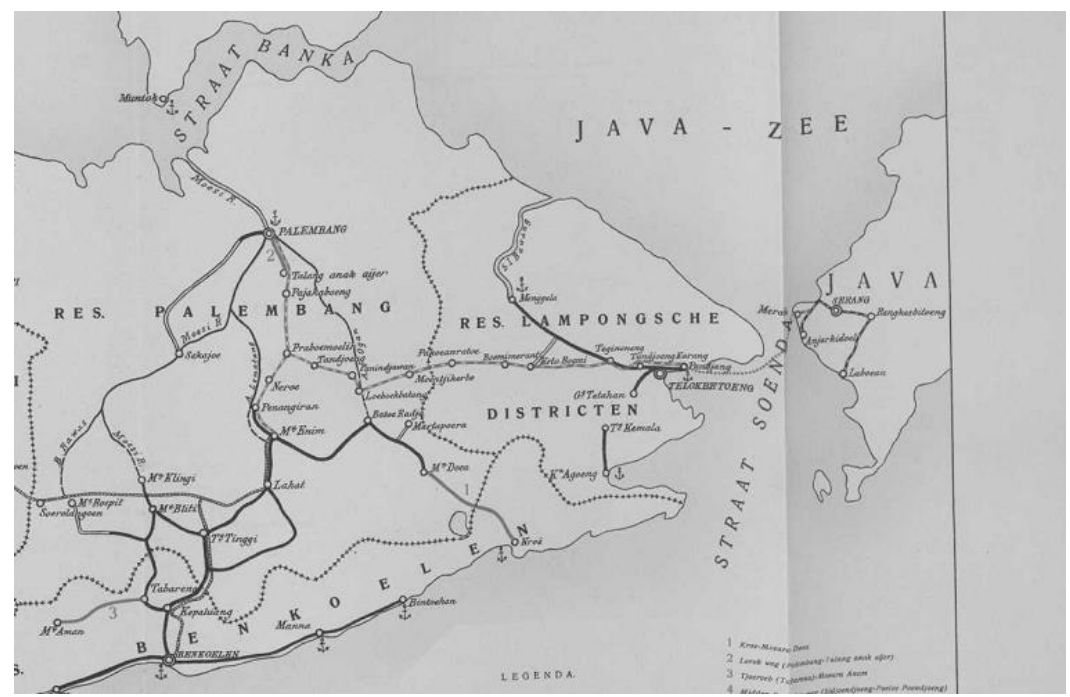

Gambar 2: Peta jalur transportasi di wilayah Lampung dan Sumatera bagian selatan.

pembangunan. Pembangunan tahap pertama meliputi jalur kereta api antara Teluk Betung (Karesidenan Lampung) hingga ke Muara Enim (Karesidenan Palembang). Pembangunan jalur kereta api Zuid Sumatra sejauh $407 \mathrm{~km}$ ini selesai pada tahun 1917. Pembangunan jalur ini sangat penting terutama dalam distribusi hasil hutan dan perkebunan, serta sumber ekonomi baru yang sangat menguntungkan yakni minyak bumi (Department van Kolonien, 1904: 68-69; Stibbe, 1921: 78). ${ }^{7}$ Di Keresidenan Lampung jalur kereta api ini menghubungkan kota-kota dari Teluk Betung, Gedong Tataan, Negeri Bumi Udik, Gunung Terang, hingga Kota Bumi. Pembangunan jalur kereta api ini dilakukan sebagian besar oleh kelompok pertama transmigran dari Jawa yang membentuk kolonisasi di Lampung pada tahun 1905 (Department van Kolonien, 1904: 68).

\footnotetext{
${ }^{7}$ Awalnya jalur kereta api lintas Sumatera bagian selatan (Zuid Sumatra Staatspoorwagen) ini direncanakan menghubungkan Teluk Betung (Lampung) hingga ke Bengkulu. Namun, akibat krisis ekonomi pada masa Perang Dunia I pembangunan jalur Muara Enim - Bengkulu pada akhirnya harus dihentikan.
}

Pada tahun 1865 pemerintah kolonial mengoperasikan Pelabuhan Teluk Betung sebagai pelabuhan utama di Keresidenan Lampung. Pelabuhan Teluk Betung awalnya merupakan pelabuhan rakyat yang berada di sekitar Teluk Lampung. Setelah berakhirnya perang pemerintah kolonial merevitalisasi pelabuhan ini sebagai terminal angkut muat barang dan terminal penumpang yang disesuaikan dengan kebutuhan dan kepentingan pengembangan ekonomi kolonial. Setelah melakukan perbaikan dan revitalisasi dari pelabuhan rakyat menjadi pelabuhan modern, Pelabuhan Teluk Betung digunakan secara resmi sebagai pelabuhan regional sejak 3 Desember 1865 (Kok, 1931: 96).

Pelabuhan Teluk Betung menjadi pelabuhan strategis yang bukan saja berperan dalam arus perdagangan lokal di Keresidenan Lampung, namun juga menjadi pelabuhan penghubung bagi arus lalu lintas perdagangan antara Batavia, Bengkulu, Padang (Sumatera Barat), Palembang, Singapura, bahkan hingga ke Makassar. Pelabuhan ini juga memiliki jaringan dengan pelabuhan-pelabuhan lain di Jawa seperti Surabaya, Semarang, 
Pekalongan, Tegal, dan Cirebon (Koloniaal Verslag, 1866: 75). ${ }^{8}$

Pelabuhan Teluk Betung termasuk ke dalam tingkat pelabuhan kecil (small harbor) di Hindia Belanda. ${ }^{9}$ Pelabuhan jenis ini biasanya hanya disinggahi oleh kapalkapal uap bertonase kecil, kapal-kapal nelayan, serta memiliki struktur bangunan yang sebagian masih terbuat dari kayu serta panjang pelabuhan yang terbatas sehingga tidak bisa disinggahi oleh kapalkapal yang besar (Department of Public Works, 1920: 79). ${ }^{10}$

Pelabuhan Teluk Betung terhubung dengan jalur kereta api yang menghubungkan pelabuhan ini hingga ke Muara Enim (Palembang). Integrasi antara pelabuhan dan jalur kereta api ini memiliki fungsi penting dalam pengembangan wilayah serta peningkatan frekuensi perdagangan di wilayah Sumatera bagian selatan. Pengaruh dari terbentuknya

\footnotetext{
${ }^{8}$ Pada tahun pertama setelah pelabuhan ini dioperasikan terdapat 34 kapal yang berasal dari Batavia, 18 kapal dari Surabaya dan Banjarmasin, 12 dari Makassar, dan 6 dari Singapura yang berlabuh di Pelabuhan Teluk Betung. (Koloniaal Verslag, 1866: 75)

${ }^{9}$ Pemerintah kolonial membagi pelabuhanpelabuhan ke dalam tiga strata yakni pelabuhan besar (seperti Batavia, Surabaya, BelawanDeli, dan Makassar), pelabuhan menengah (seperti Cirebon, Tegal, Banjarmasin, dan Pontianak), serta pelabuhan kecil (Teluk Betung, Timor, dan Bagan Siapi-api). Klasifikasi ini didasarkan pada letak wilayah, komoditas, serta volume perdagangannya. Hal ini dilakukan untuk memberikan prioritas pembangunan dan pengembangan dari pelabuhan-pelabuhan tersebut (Department of Public Works, 1920: 7).
}

${ }^{10}$ Pada tahun 1912 Pelabuhan Teluk Betung hanya sanggup menerima satu kapal lintas samudera (large going sea vessel) dalam satu kesempatan bongkar muat atau dua kapal kelas menengah (coasting steamer). Hal ini disebabkan oleh panjang dermaga yang kecil, namun kecepatan bongkar muat di pelabuhan ini sangat tinggi karena penggunaan teknologi derek terbaru pada masa itu (Department of Public Works, 1920: 80). jaringan antara pelabuhan dan kereta api ini adalah pengembangan wilayah komersial dan hunian di sekitar affdeeling Teluk Betung yakni perkembangan wilayah Tanjung Karang. Wilayah Tanjung Karang yang berada di wilayah yang lebih tinggi berkembang menjadi sebuah kota dagang yang ramai (Department of Public Works, 1920: 80).

\section{PENUTUP}

Perkebunan menjadi sektor andalan ekonomi Lampung pada masa kolonial. Lada, karet, kopra, kopi, dan tembakau merupakan tulang punggung ekonomi Lampung pada masa tersebut. Sektor pertambangan yang ditunjang oleh keberadaan eksploitasi pasir besi mejadi alternatif pendapatan ekonomi dari wilayah ini. Pemberian konsesi bagi para pengusaha dengan jaminan perlindungan dari pemerintah mendorong eksploitasi ekonomi yang terstruktur dan turut membuka pusat-pusat ekonomi baru di wilayah ini. Kekurangan pekerja akibat perkebunan-perkebunan baru yang tumbuh secara serentak sejak pertengahan abad ke19 seakan tidak menjadi masalah ketika kebijakan kolonisasi yang dilakukan pemerintah di balik bayang-bayang Politik Etis menjadi pemecahan dari masalah tersebut. Meningkatnya pertumbuhan penduduk akibat kolonisasi juga turut berperan bagi pertumbuhan ekonomi dengan meningkatnya konsumsi masyarakat.

Namun faktor yang menentukan bagi seluruh rangkaian pertumbuhan ekonomi di kawasan Lampung selepas perang hingga malam menjelang "Depresi Besar" tahun 1930 yakni pertumbuhan sektor komunikasi dan transportasi. Pembangunan sektor infrasruktur di wilayah Sumatera menjadi faktor penting yang menumbuhkan pertumbuhan ekonomi di kawasan ini. Perbaikan dan pembangunan jalan raya, jalur kereta api, dan pelabuhan menjadi titik balik ekonomi di kawasan Sumatera maupun selepas rangkaian konflik politik dan kekerasan di 
awal abad ke-19 yang menghancurkan sektor-sektor ekonomi penting di kawasan ini. Penemuan komoditas perdagangan baru seperti karet, batu bara, dan minyak bumi tentu membutuhkan sarana distribusi yang cepat dan efisien. Jarak yang cukup dekat antara Lampung dengan Banten menjadikan Lampung bukan saja sebagai gerbang ekonomi bagi Pulau Sumatera namun juga gerbang ekonomi dan energi bagi Pulau Jawa dengan Selat Sunda dan Laut Jawa sebagai "tol laut" pada masa tersebut.

\section{DAFTAR SUMBER}

\section{Arsip}

Koloniaal Verslag, 1858.

Koloniaal Verslag, 1859.

Koloniaal Verslag, 1866.

Koloniaal Verslag, 1920.

Staat der Bevolking tan de bezzittingenbuiten Java en Madoera, 1860.

\section{Tesis}

Rijal, Andi Syamsu. 2011.

Dua Pelabuhan Satu Selat: Sejarah Pelabuhan Merak dan Pelabuhan Bakauheni di Selat Sunda 1912-2009. Tesis. Fakultas Ilmu Budaya, Jurusan Ilmu Sejarah, Univeritas Indonesia.

\section{Jurnal}

Ariwibowo, Gregorius Andika. 2017.

"Sungai Tulang Bawang dalam Perdagangan Lada di Lampung pada Periode 1684 Hingga 1914". Jurnal Masyarakat dan Budaya, Vol. 19, No. 2 Tahun 2017, hlm. 253-267.

Ota, Atsushi. 2005.

'From 'Piracy' to Inter-regional Trade: the Sunda Straits Zone, c. 1750-1800" IIASS Newsletter, \#36, hlm. 9.

\section{3.}

"Tropical Products Out, British Cotton In: Trade in the Dutch Outer Islands Ports, 1846-69". Southeast Asian Studies, Vol. 2, No. 3, December 2013, hlm. 499-526.

\section{Buku}

Anonim. 1918.

De Pepercultuur in de Buitenbezittingen. Batavia: Landsdrukkerij.

Asnan, Gusti. 2016.

Sungai dan Sejarah Sumatera. Yogyakarta: Penerbit Ombak.

Badan Pusat Statistik Lampung. 2015. Statistik Daerah Provinsi Lampung 2015. BPS: Bandar Lampung.

Blink, H. 1926.

Opkomst En Ontwikkeling Van Sumatra Als Economisch Geographisch Gebied. 's-Gravenhage: Mouton \& Co.

Braudel, Fernand. 1983.

Civilisation \& Capitalis $15^{\text {th }}-18^{\text {th }}$ Century: The Wheels of Commerce, Vol. 2. London: Williams Collins Sons \& Co.

De Graaf, S., dan D. G. Stibbe. 1918. Encyclopaedie van Nederlandsch Indie, Tweede Deel. S-Gravenhage: Martinus Nijhoff.

Departement van Binnenlandsch Bestuur. 1915.

De Buitenbezittingen 1904 tot 1914, Deel I. Weltevreden: Fillal Albrecht \& Co.

Department of Public Works. 1920.

Harbourworks: Netherland Indies Harbour. Batavia Department of Public Works.

Department van Kolonien. 1904. Spoorwegverkenning in Zuid Sumatra. Batavia: Javasche Boekhandel \& Drukkerij.

Dick, Horward. dan Peter J. Rimmer. 2003. Cities, Transports, and Communication: Integraion of Southeast Asia since 1850. London: Palgrave McMillan.

Direktur Jenderal Perkebunan. 2014. Statistik Perkebunan Indonesia: Kopi. Jakarta: Direktorat Jenderal Perkebunan.

Kielstra, E.B. 1915.

"De Lampongs" dalam Onze Eeuw. Jaargang 15. hlm. 244-267. Haarlem: Erven F. Bohn.

Kok, J.A. 1931.

De Scheepvaartbescherming in Nederland en in Nederlandsch-Indie. 
Leiden: N.V. Leidsche

Uitgeversmaatschappij.

Levang, P. dan Sevin G. 1989.

80 Years of Transmigration in

Indonesia. Jakarta: Departemen

Transmigrasi Biro Perencanaan.

Marsden, William. 2013 (1810).

History of Sumatra: Containing an Account of The Government Law, Customs, and Manners of The Natives Inhabittans. Cambridge: Cambridge University Press.

Ota, Atsushi. 2015.

"Toward a Transborder, MarketOriented Society: Changing Hinterlands of Banten, c. 1760-1800" dalam Mizushima, Tsukasa., Souza, George Bryan., Flynn, Dennis O. Hinterlands and Commodities: Place, Space, Time and the Political Economic Development of Asia Over the Long Eighteenth Century. Leiden, Boston: Brill.

Pelabuhan Indonesia II (Persero). 2012.

Energizing Trade Energizing Indonesia: Laporan Tahunan 2012. Jakarta: Pelabuhan Indonesia II (Persero).

Steck, F.G. 1862.

"Topographische en Geograpische Beschrijvingder Lampongsche Distrikten”. BKI, Volume 8, Issue 1.

Stibbe, D.G. 1921.

Encyclopaedie van Nederlandsch Indie, Vierde Deel. S-Gravenhage: Martinus Nijhoff.

Tagliocozzo, Eric. 2010.

The Indies and The World: State Building, Promise, and Decay at Transnational Moment. BKI, Volume 166, Issue 2-3.

Wellan, J.W.J. 1932.

Zuid-Sumatra: Economisch Overzicht. Wagenigen: H.Veenan \& Zonen.

\section{Internet}

Kwan, Jenny dan Cervone, Carl. 2014.
"Indonesia:
A business case for
coffee production". sustainable coffee production". www.sustainablecoffeeprogram.com/site /getfile.php?id=230. Diakses pada 12 Desember 2017 pukul 10.32. 